\title{
Damping-off of sugar beet with special reference to the fungus Pythium Pringsheim
}

\begin{abstract}
In Finland damping-off of sugar beet can be divided into two distinct phases. The first phase begins with the germination of the seeds and continues until the first true leaves have developed. Under field conditions seedlings usually remain healthy up to about 1 week after emergence. Thereafter a sudden outbreak of damping-off may occur, resulting in rapid wilting and death of seedlings. During the second phase of the disease, when seedlings have one or more pairs of true leaves, disease does not always result in the death of the plant; plants may survive throughout the summer.

At the pernicious phase of the disease the soil borne pathogen, Pythium debaryanum auct. non Hesse, is the most common causal agent, accounting in 1979-86 for $53.9 \%$ (variation between years $18.3-90.1 \%)$ of fungal isolations, and Fusarium species for $28.3 \%$ (5.0-58.5 $\%$ ). At seedling stages with one or more pairs of true leaves Fusarium spp. predominate accounting for $49.4 \%(36.1-81.0 \%)$ as compared to $23.9 \%(2.9-37.8)$ for $P$. debaryanum. The importance of Fusarium species as true damping-off pathogens is, however, doubtful. The seed borne damping-off pathogen Phoma betae Frank was isolated only in 0 to $4 \%$ and was not dependent on the stage of seedling development.

Of the factors affecting damping-off, high temperatures were repeatedly shown to increase the disease. This, presumably was an effect especially on $P$. debaryanum, the aggressiveness of which is strongly increased at high temperatures.

Pot experiments showed preceding crops of cereals to have the best disease-decreasing effect, both short-term (one growing period of preceding crop) and long-term (several growing periods of preceding crop) effect. Legumes kept the level of damping-off unchanged or even raised it, especially as a short-term effect. The influence of preceding crops varied in different soil types. Preceding crops also caused considerable fluctuations in inoculum density ( 0 to 3650 propagules/gram soil) and potential (0.2-16 IPU ${ }_{50} / \mathrm{gram}$ soil) of Pythium. The correlation to damping-off of sugar beet was, however, poor.

Seed treatment with the systemic fungicide hymexazol, especially when combined with thiram, prevented satisfactorily the pernicious type of damping-off. In many experiments this seed treatment repeatedly decreased disease incidence significantly, produced denser stands $(7100-31200$ numbers of beets more/hectare) and increased yield by $5-10 \%$ on average.
\end{abstract}




\section{List of original articles}

The original articles summarized here are:

I. Vestberg, M., Tahyonen, R., Raininko, K. \& Nuormala, N. 1982. Damping-off of sugar beet in Finland. I. Causal agents and some factors affecting the disease. J. Sci. Agric. Soc. Fin. 54: 225-244.

II. Vestberg, M., Tahvonen, R., Raininko, K. \& Nuormala, N. 1983. Damping-off of sugar beet in Finland. II. Disease control. J. Sci. Agric. Soc. Fin. 55: 431-450.

III. Vestberg, M. 1984. Damping-off of sugar beet in Finland. III. Effect of temperature and disease forecasting. J. Agric. Sci. Fin. 56: 283-290.

IV. Vestberg, M. 1985. Experiments on direct isolation of Pythium spp. from Finnish sugar beet soils. J. Agric. Sci. Fin. 57: 223-230.

V. Vestberg, M. 1987. The effect of preceding crops on damping-off of sugar beet and some ecological properties of the fungus Pythium Pringsh. J. Agric. Sci. Fin. 59: $87-100$.

Reference to these publications is made in the text by citing the appropriate Roman numerals. 


\section{Introduction}

Damping-off is defined as the collapse and falling over of young seedlings and herbaceous cuttings caused by the attack of various organisms at or below soil level (Mc KAY 1952).

In Europe in 1968-1970, the greatest losses due to damping-off of sugar beet occurred in Poland, Romania, Czechoslovakia, Hungary and Ireland (DuNNING 1972). In 1979-1980, the main disease causing factors at the seedling stage in 16 European countries were in the decreasing order of frequency: Phoma (13), Pythium (13), Aphanomyces (8), Rhizoctonia (6), Fusarium (3) and Alternaria (2) (DunNing and Heijbroek 1981).

Damping-off investigations from the Nordic countries are relatively few. In 1945, BJörLING published a very valuable work on Phoma betae. In Finland, Linnasalmi (1952) studied damping-off of a number of vegetables and ornamental plants. Other investigations on damping-off of sugar beet have been done by e.g. Möllerström and KlinteberG (1964), RASMUSSEn (1967), LinNASAlmi (1970) and Móllerström (1974).

Damping-off has since long been a wellknown disease among Finnish sugar beet growers. Earlier, when using the normal diploid multigerm beet seed, the amount of seeds used for sowing was great and growers could afford to lose seedlings because of damping-off. In the late $60 \mathrm{~s}$ a new type of sugar beet seed, genetic monogerm seed, was introduced in Finland. This made it possible to rationalize the cultivation technique by sowing into stands of final density. Now the growers could no longer afford to lose seedlings. Hence the importance of damping-off of sugar beet increased and has been estimated to be the main reason for thin brairds in the $70 \mathrm{~s}$. Yearly 150-300 hectares of almost completely destroyed beet stands have been resown. In
1979-1980 with heavy attacks of dampingoff the total yield of Finnish sugar beets was estimated to decrease by about $8 \%$ as a result of damping-off (RAININKo and VestberG 1981).

The aim of this study was to identify the causal agents of the disease, to study factors affecting the disease and to find ways to control it. Special attention was paid to the fungus Pythium and its role in the damping-off disease.

\section{Results and discussion}

\section{Disease symptoms}

In Finland, damping-off of sugar beet can be divided into two distinct phases (I) similar to those described by WARREN (1948). First, there is the very severe phase, which rapidly results in the death of the seedlings. This phase begins with the germination of the seed and continues until the development of the first true leaves. WARREN (1948) further even divided this phase into a pre-emergent and a post-emergent phase. In Finland, preemergence damping-off occurs only during some years and at some localities. This type of damping-off can be observed as gaps in the braird at the time of emergence. Usually, however, seedlings emerge quite well and the first disease symptoms appear only $7-10$ days after emergence.

Infection at the cotyledon stage soon after emergence usually leads to complete wilting and rapid death of the plant. A water-soaked, brown to grey or black area extends up and down the hypocotyl or the upper portion of the young taproot from the point of entry of the pathogenic organism. Discoloration may also, in later stages extend up into the peti- 
oles of the cotyledons. The collapse of the hypocotyl of the seedling is followed by desiccation. Under favourable conditions this development may take place within $1-2$ days (I).

The second phase of the disease is characterized by the seedlings not being immediately killed; they may stay alive for quite a long time. Such diseased seedlings have a dark thread-like root. The disease is, however, restricted to the cortex, which explains why the seedlings do not die. If the disease advances to the vascular bundle of the root, the seedling will die (Butler \& Jones 1961). However, the neck collar is weak and typically constricted thus, later in the summer they easily break at the root collar due to strong winds or agricultural proceedings. In the autumn at harvesting the abnormally developed beets can easily be separated from the healthy ones. It was shown that the weather conditions in July and August determine how well seedlings will recover from the second phase of dampingoff (I). In summers with high temperatures and sufficient rainfall the recovery is better than in cool summers. Chronic damping-off, which appears after the true damping-off phase, is sometimes also named "strangles", which refers to symptoms caused by abiotic factors such as strong winds or dry soil (BOyD 1966, Schollmeyer 1980). Acid soils are also reported to cause damping-off-like injuries in beet seedlings (GATES and Hull 1954). Under Finnish conditions, however, it seems clear that damping-off of sugar beet is mainly caused by microorganisms and not by abiotic factors (I).

Damping-off of sugar beet usually appears in the same field during several years in succession and the appearance is clearly patchy. Sometimes the disease proceeds along the row, not from one row to another.

In this study no attempts were made to identify causing organisms on a macroscopic level. Such an identification is difficult to make because the symptoms caused by different species of microorganisms do not differ much from each other (COONS and STEWART
1927, BenADA et al. 1987). In many cases there are also mixed infections (Coons and Stewart 1927). However, CoOns and Stewart (1927) and MC Kay (1952) divided the symptoms into three groups, which can be connected to certain damping-off pathogens:

1) Phoma betae: The affected hypocotyl turns brownish to black. The lesions are dry and the attack is chiefly confined to the cortex of the stem. The destruction of the seedling is rather slow.

2) Pythium and Aphanomyces: There is often a rapid wilting of seedlings. The lesions are soft and water-soaked.

3) Rhizoctonia solani: This fungus causes rather dry, brown lesions, which spread slowly. The taproot is often decayed, which initiates the development of rootlets above the decayed region.

\section{Causal agents}

Introductory experiments to study the causal agents of damping-off on sugar beet were carried out in a glasshouse by studying the damping-off microflora of 48 soil samples from different parts of the Finnish sugar beet growing district (I). A fungus of the genus Pythium was found very frequently. According to the key of WATERHOUSE (1967), the species was named $P$. debaryanum auct. non Hesse. Just after emergence $P$. debaryanum accounted for about $95 \%$ of the total fungal isolates and 35 days after emergence still for $78 \%$. Correspondingly, other damping-off pathogens occurred sparcely, Fusarium spp. averaged $2.8 \%$, Phoma betae $2.2 \%$ and Rhizoctonia solani $0.4 \%$.

The damping-off flora of sugar beet seedlings grown in the field was studied in 1979-86 (Table 1). A total of about 8400 seedlings were studied. Study I presents the results of the years, 1979-1981. Diseased seedlings were collected at the cotyledon stage, 7-10 days after emergence. A second collection was made about 20 days after emergence. Similarly to the pot experiment, $P$. debarya- 
num was the most common fungus, especially at the cotyledon stage, accounting for 53.9 $\%$ of the fungal isolations. Under field conditions the fungus was not, however, so dominating as it was in the pot experiment. Variations between different years were also considerable, $18.3-90 \%$ in 1979-1986, which indicates the importance of climatological factors.

The results of this study are in agreement with those of BuchHoltz (1938), Nölle (1960), Peshel (1969) and Kühnel (1978) according to which the most widely distributed damping-off pathogens on sugar beet belong to the genus Pythium. Within the genus, the species $P$. debaryanum Hesse, $P$. ultimum Trow and $P$. aphanidermatum (Edson) Fizp. are the most commonly isolated (BuCHHOLTZ 1938, Hills and LeACH 1952, Gates and Hull 1954, Till 1968, Linnasalmi 1970, Böttcher and BEHR 1980). P. aphanidermatum is found especially in the United States (TILL 1968, TAKAHASHI et al. 1972). Other isolated species of Pythium include P. irregulare Drechs. (Veselý 1978, Böttcher and Behr 1980), $P$. spinosum Sawada apud Sawada \& Chen (TAKAHASHI et al. 1972), $P$. mamillatum Meurs (Meurs 1928), P. elongatum Matth.,

Table 1. Frequency of damping-off pathogens on sugar beet in 1979-86: a) about $7-10$ days after emergence ( 3900 seedlings studied) and b) about 20 days after emergence (4500 seedlings studied).

Pathogen
Isolated pathogens $\%$ of all fungal isolations

Average Yearly
1979-86 variation

a) $7-10$ days after emergence Fusarium spp. Phoma betae Pythium debaryanum Rhizoctonia solani

b) 20 days after emergence Fusarium spp. Phoma betae Pythium debaryanum Rhizoctonia solani
$5.0-58.5$ $0-4.0$

$18.3-90.1$ $0-3.1$
49.4

1.4

23.9

0.2
$36.1-81.0$

$0-3.3$

$2.9-37.8$

$0-0.8$
$P$. paroecandrum Drechs., $P$. echinulatum Matth. and $P$. rostratum Butl. (BöTtCHER and BEHR 1980).

The actual position of the Pythi..m species found most commonly in this investigation is not clear. According to the latest taxonomic studies on Pythium, there exists no species named $P$. debaryanum (VAn DeR PlaAtsNITERINK 1981). Isolations of $P$. debaryanum have in fact proved to be misidentifications of either $P$. ultimum, $P$. intermedium, $P$. irregulare or even of $P$. sylvaticum. In this study, however, the species of Pythium found very commonly in Finnish sugar beet soils is named $P$. debaryanum after W ATERHOUSE (1967).

At the second collection, Fusarium species were the most frequently isolated. Of all the fungal isolations made, they accounted for $49.4 \%$ as compared to $23.9 \%$ for $P$. debaryanum. Out of seven species of Fusarium isolated, F. culmorum (W.G. Sm.) Sacc., F. oxysporum Schlecht. and $F$. sambucinum Fuck. were predominating. All these species are common soil saprophytes (DoMsch et al. 1980), and their actual role as damping-off pathogens is not established. According to Hodges (1936), Möllerström and Klinteberg (1964) and BöTtCHER and BEHR (1980), Fusarium species can be considered primary pathogens on sugar beet seedlings. GATES and HulL (1954) found the species of Fusarium to be weak damping-off pathogens in acid soils $(\mathrm{pH}<6.5)$. In Finnish mineral sugar beet soils $\mathrm{pH}$ is about 6.3 (Pelo 1987), which would indicate pathogenicity of Fusarium as a damping-off pathogen. However, in pathogenicity tests, three Fusarium species caused no disease when inoculated into peat substrate. $P$. debaryanum and $P$. betae, on the contrary, caused disease symptoms in beet seedlings under the same experimental conditions (I). In extensive pathogenicity experiments LINNASALMI (1952) also found Fusarium species to be only slightly or not at all pathogenic as causal agents of damping-off on cabbage, cauliflower, cucumber and tomato. VESELÝ (1976) isolated 10 species of Fusarium from 
diseased sugar beet seedlings. Although all species were only slightly pathogenic, they caused excessive root branching in emerging seedlings.

Isolations of $P$. betae varied between 0 and $4.0 \%$ according to sampling time and year (Table 1). The general occurrence of this fungus was not dependent on the stage of seedling development. According to many investigations, $P$. betae is an equally important damping-off pathogen as Pythium on sugar beet (MC KAY 1952, Nölle 1960, MöllerSTRÖM 1964, LeACH and MaCdONALD 1976). LinNASALMi (1970), in an earlier Finnish investigation also found $P$. betae to be the most common fungus on diseased sugar beet seedlings, followed by Pythium debaryanum and Fusarium spp. . Because $P$. betae is a seed borne pathogen and can hardly overwinter in the soil (Pool and Mc KAY 1915, Mc KAY 1952), the reason for the decline as a causal agent of damping-off in Finland must be that the sugar beet seeds are quite free from infection.

The fungi Alternaria alternata and Ulocladium consortiale (Thüm)Simm were isolated rather frequently in some years (I), but the pathogenicity of these fungi is mostly weak (VESELY 1977b), although contradictory opinions also exist (Greis 1940, HeIDEL and SChultze 1984). In this study, the dampingoff pathogen Rhizoctonia solani was found only in a few samples. Generally, species of Rhizoctonia, i.e. $R$. solani (CoONS and Stewart 1927, Hills and Leach 1952) and $R$. violacea(Tul.)Pat (Afanasiev and Morris 1942, BENADA et al. 1987), have not been found to be as important pathogens on sugar beet as Pythium and Phoma betae.

Species of the soil borne fungus Aphanomyces commonly give rise to damping-off on sugar beet both in Europe (SChäUfele and Winner 1972, ByFord and Stamps 1975) and the United States (CoOns et al. 1948, Papavizas and Ayers 1976). However, in this study, no species of Aphanomyces were found. As can be decided from their occurrence, only fungi belonging to the genera Pythium and Fusarium have any significance as damping-off pathogens on sugar beet in Finland.

\section{Factors affecting the disease}

BJöRLING pointed out already in 1945 that beet damping-off is a pronounced predisposition disease, which is affected by different abiotic and biotic factors like soil and climatic conditions. In practice, this appears as variations in the occurrence of damping-off between years and fields and even within fields. Whithin fields the damping-off shows a typical patchy appearance, the reason for which is not fully understood (BuchHOLTz 1938).

\subsection{Abiotic factors}

\subsubsection{Soil type}

There are diverging opinions about the role of soil type in damping-off of sugar beet. According to Gram (1927), the physical conditions of the soil are more important than the soil type. Coons and Stewart (1927) agree with this, but at the same time they claim that the most severe outbreaks of damping-off appear on heavy soils and highly organic soils. However, contrary to this, Gates and Huli (1954) found lower incidence of damping-off in clay soils than in light soils. Remy (1950) found damping-off in all kinds of soils, but more frequently in clay than in sand. URBANOVICH (1965) found a correlation between the humus content of the soil and dampingoff incidence. Angell (1954) isolated the damping-off pathogen Pythium mainly in the uppermost soil layers and in coarser soil types. According to LikaIS (1948), the aggressiveness of $P$. debaryanum is related to the colloid content of the soil. At lower colloid contents the aggressiveness will decrease. On the other hand, Nölle (1960) found no differences in the agressiveness of Pythium inoculated into compost or mineral soil.

In this investigation, the content of humus or clay was determined in 47 soil samples from 
heavily infested sugar beet fields (I, Table 4). The humus content varied between $1.7 \%$ and $44.3 \%$ and the clay content correspondingly between $2 \%$ and $73 \%$. However, no correlations were found between these figures and the incidence of damping-off. These results are in agreement with those of GrAm (1927) and BuCHHOLTz (1938).

\subsubsection{Soil acidity}

Many authors have found a correlation between $\mathrm{pH}$ and the severity of damping-off of sugar beet. ARRHENIUS (1924) claims that raising the $\mathrm{pH}$ to $7.2-7.6$ by the use of lime will contribute to better control of Pythium damping-off. Other investigations show similar associations between $\mathrm{pH}$ and damping-off (Mc Kay 1952, Griffin 1958). On the other hand, damping-off of sugar beet caused by the seed-borne pathogen Phoma betae is not dependent on soil acidity. It may occur also in strongly alkaline soils (ARRHENIUS 1924, Mc KAY 1952).

In this study, the $\mathrm{pH}$ values of 47 soil samples from infested sugar beet fields varied between 5.1 and 6.9 (mean 6.2). No correlation, was noticed between $\mathrm{pH}$ and damping-off (I, Table 4). In a pot experiment, the raising of $\mathrm{pH}$ from 5.2 to 6.6 by the use of lime had a significant disease decreasing effect (II, Table 5 ). The effect of liming and higher $\mathrm{pH}$ levels on damping-off of sugar beet was studied under field conditions during two years (II, Tables 15 and 16). Only a very slight disease decreasing effect was noticed. In one experiment, liming decreased the sugar content of the beetroots (II, Table 16). The acidity of Finnish sugar beet soils is often quite pronounced. Therefore it is not in practice possible by liming to raise the $\mathrm{pH}$ values of the fields to $7.2-7.6$ which would control damping-off, as suggested by ARRHENIUS (1924). On the other hand, BuchHoltz (1938) found good mycelial growth of Pythium within the $\mathrm{pH}$ values 5 and 7.5 , which indicates that Pythium damping-off could be severe even on alkaline soils. Calcium, a component of lime, on the other hand, has been shown to stimulate production of oospores of Pythium in vitro, which would increase the damping-off potential of the soil (HASKINS 1965, Lumsden and Ayers 1975).

\subsubsection{Soil nutrients}

Generally, a balanced mineral level in the soil provides plants the best possibilities to prevent attacks by damping-off. Phosphorus is reported to have a preventive effect against damping-off (AfanASIEV and CARLSON 1943, Möllerström and Klinteberg 1964). However, in this investigation no correlation was observed between the level of phosphorus and damping-off in sugar beet (I, Table 4). The amount of potassium, sodium or magnesium in the soils studied correlated slightly to damping-off, which is in agreement with Yale and Vaughan (1962). Manure has also shown a preventive effect against damping-off (Afanasiev and Carlson 1943, Young 1943).

\subsubsection{Moisture}

Soil moisture is an important concept determining germination and growth of microorganisms. The frequency of, for example, bacteria occurring on buried slides or within potato lenticles decreases rapidly below field capacity. The clamydospores of Fusarium culmorum, which germinate in very dry soil, even at soil water potentials down to -85 bar are another extreme. Pythium spp. and Mortierel$l a$, on the other hand, colonized buried plant parts most frequently in relatively wet soils at soil-water potentials exceeding -1 bar. (GRIFFIN 1972).

BuchHOLTZ (1938) found no significant differences in soil moisture between healthy and diseased areas within sugar beet fields. Several authors (ROTH and RiKER 1943, ZhukOva 1953, BARTON 1958) report an increase in aggressiveness of Pythium dampingoff close to water saturation. According to Doran (1946) and Zhukova (1953), an increase will be observed in Pythium dampingoff when soil moisture exceeds $65 \%$. 
In Finland, soil moisture is usually high after the melting of snow in spring, during the initial development of the sugar beet seedlings (BRUMmer 1960). This is a prerequisite for a rapid infection of the seedlings by Pythium. At high soil moistures the thick cell walls of dormant Pythium oospores become thin. During germination such oospores readily infect hypocotyls of young seedlings (HOPPE 1966, LUMSDEN and AyERs 1975). High soil moisture is also a prerequisite of saprophytic growth of Pythium in soil (Hendrix and CAMPBell 1973). Later on, in June, dry periods with quite high temperatures are not rare. This might contribute to the common occurrence of Fusarium species in damping-off diseased beet seedlings at this time (I). It has been shown that Fusarium species are favoured by low soil moisture, even down to $30 \%$ of saturation (SHEN 1940).

\subsubsection{Temperature}

Of all the physical variables of biological significance, temperature is perhaps the most obvious. Even during one day, a fluctuation of $35^{\circ} \mathrm{C}$ may occur at the soil surface in temperate zones (RuSSELl 1961). With increasing depth, the fluctuations of diurnal temperature are reduced and approach a mean value. This might be only $10^{\circ} \mathrm{C}$ in summer in temperate climates (GRIFFIN 1972).

In Denmark, Miḱelsen (1982) tried to compare the general occurrence of dampingoff with temperature during May-June in 1954-82. He found heavy outbreaks in warm early summers, while the disease remained at a low level in cool summers. This could be noticed also in Finland when comparing average temperatures in the early summers of 1979-87 (HELMINEN 1979-1987) with average damping-off percentages in sugar beet experiments during these years. This relation could, however, not be statistically verified.

The effects of high temperatures on the increase of damping-off was demonstrated in a pot experiment at $8^{\circ} \mathrm{C}$ and $18^{\circ} \mathrm{C}$ (I, Table 2). Damping-off averaged $26.7 \%$ and $54.1 \%$ respectively.
In practice there is often a very rapid outbreak of damping-off following a period of high temperatures. Periods of $20-25^{\circ} \mathrm{C}$ daily temperatures are not rare during the early seedling stage of sugar beet in late May or in June. By the use of climate chambers the effect of periods of high or low temperatures before or after emergence on the severity of damping-off was studied. Two highly infested sugar beet soils were used (III). A constant low temperature $\left(15^{\circ} \mathrm{C}\right.$ day and $8^{\circ} \mathrm{C}$ night) gave rise to an average damping-off of $45 \%$ as compared to $97 \%$ at constantly high temperature $\left(25^{\circ} \mathrm{C}\right.$ day and $15^{\circ} \mathrm{C}$ night) (III, Table 1). When the pots were kept at low temperature up to emergence and at high temperature thereafter, the degree of damping-off was the same as in seedlings grown at continuously high temperatures. The opposite situation gave a damping-off incidence of $62 \%$ which indicates that damping-off had started during the pre-germination phase. At least a 7-day period of high temperature was needed to cause an increase of disease if the pots had been held at low temperature up to emergence. In the peat soil, at 14 day's period of high temperatures was needed to increase disease significantly. The length of the warm period correlated significantly with the degree of damping-off $\left(\mathrm{r}=0.938^{* * *}\right.$ and $0.800^{* * *}$, respectively) (III).

When evaluating the role of temperature on damping-off, the temperature requirements of different causal agents should be taken into consideration. The optimum in vitro growth rate of Pythium debaryanum is observed at 25-30 ${ }^{\circ} \mathrm{C}$ (BuchHoltz 1938, Middleton 1943). Under natural conditions, in the soil, the optimum occurs at somewhat lower temperatures due to competition from antagonists at the higher temperature (SvERRISSON 1979, Lifshitz and Hancock 1983). Phoma betae has a somewhat lower optimum than $P$. debaryanum. BJörLING (1945) found an optimum germination of pycnospores of $P$. betae at $20-25^{\circ} \mathrm{C}$ and some germination even at $0^{\circ} \mathrm{C}$. In practice, damping-off of sugar beet caused by $P$. betae is favoured by low soil tem- 
peratures (JACKS 1951, GATES and Hull 1954, Nölle 1960). Comparing the growth of $P$. betae and $P$. debaryanum, Nölle (1960) found a tenfold faster growth per ${ }^{\circ} \mathrm{C}$ of the latter at $5-12^{\circ} \mathrm{C}$. The species Fusarium culmorum, $F$. oxysporum and $F$. sambucinum, found most frequently in this study (I), all have optimum in vitro growth at $25-30^{\circ} \mathrm{C}$ (Domsch et al. 1980).

In Finland, the soil temperature at and after sugar beet seedling emergence is about $10-12^{\circ} \mathrm{C}$ at a depth of $20 \mathrm{~cm}$ (HELMINEN 1979-1987) and exceeds that greatly at the soil surface. This favours Pythium dampingoff and Fusarium fungi as well. BucHноLTZ (1938) and Nólle (1960) consider $+15^{\circ} \mathrm{C}$ a critical point, above which the aggressiveness of Pythium damping-off increases rapidly. Temperature also affects the pre-emergence/ post-emergence damping-off ratio (I, Greeves and Muskett 1936, Buchholtz 1938). A high temperature gives good emergence, but emergence is closely followed by an outbreak of disease. At low soil temperature the germination is slow and proportionally poorer than at high temperature, but the final survival of seedlings is higher than at high temperature.

Meteorological factors such as temperature and humidity act on the pathogen or on the host or on both when brought into association. Therefore it may often be difficult to decide how much of a disease increase is attributable to decreased seedling resistance to a pathogen and how much to increased aggressiveness of the pathogen. MiKKELSEN (1982) emphazises that beet seedlings grow very rapidly at high temperatures. This will result in elongated thin-walled cells, which are very sensitive to attacks of damping-off.

\subsection{Biotic factors}

There are three basic ecological properties of soil borne fungi, which influence the disease expression: inoculum density (ID), inoculum potential (IP) and competitive saprophytic ability (CSA) (Bочнот 1979). These con- cepts are useful when studying, for example, environmental factors (temperature, soil moisture, $\mathrm{C} / \mathrm{N}$ ratio, preceding crop, etc.) or the mechanisms of biological control (BAKER 1971), or they may be used to forecast soil borne diseases.

Introductory studies of ID and IP of Pythium were made in order to get a better picture of the variations in Pythium damping-off on sugar beet.

\subsubsection{Inoculum density of Pythium}

\subsubsection{Concept}

Inoculum density is quantitatively measured as the number of propagules of a pathogen per gram of dry soil (Вочнот 1979). There are many investigations on the quantitative relationship between ID and soil borne diseases, with e.g. Pythium spp. (Mitchell 1978, FERriss 1982), Rhizoctonia solani (VAN Bruggen et al. 1986), Fusarium spp. (Guy and BAKer 1979) and Phytophtora (MrTCHell 1978).

For direct quantitative isolation of Pythium from soil, WARCUP's (1950) soil plate method has proved superior to the dilution plate method. SCHMitTHENNER (1962) used a soil-particle technique for isolation of $P . u l$ timum and several other Pythium species from soil particles. Stanghellini and Hancock (1970) found that $P$. ultimum grew out from small drops dispersed on the surface of 3-dayold water agar and that this method could be quantified by making dilutions. In the present study, Pythium species were successfully isolated directly from soil and the ID was measured using the soil-plate method of WARCUP (1950) as modified by Ricci et al. (1976). According to this method, small amounts of oven-dried soil were evenly dispersed in $2.5 \%$ water agar at $40-42^{\circ} \mathrm{C}$. Citric acid, $50 \mathrm{ml} / \mathrm{l}$, was added to the agar before autoclavation. After solidification of the agar, round discs, $1 \mathrm{~cm}$ in diameter, were cut out and transferred to the Pythium selective medium, Martin's (MARTIN 1950) agar to which benomyl and PCNB had been added (15 ppm of each). The 
agar plates were incubated for $24 \mathrm{~h}$ at $15^{\circ} \mathrm{C}$ in the dark, after which they were exposed to normal daylight and darkness. After four days, the number of plates with mycelia of Pythium was recorded and the number of propagules per gram of dry soil was calculated according to the MPN method (MALOY and Alexander 1958) (IV).

\subsubsection{Applications}

The method yielded 4 types of soil borne Pythium species from sugar beet soils including the pathogenic type (IV, Fig. 1). However, this type could not be distinguished from the saprophytic ones without inoculation experiments with every strain (Bоuнот 1979). The method proved good for estimating propagule densities of very heavily infested soils, but it is not useful to detect low oospore densities of, for instance, 1 propagule or less per gram of soil.

In pot experiments propagules of Pythium numbered from near 0 to 3650 in naturally infested sugar beet field soil after different preceding crops (V, Fig. 1, 2, Table 4). The ID of Pythium correlated, however, poorly with damping-off of sugar beet seedlings. Unexpectedly, in some cases a significant negative correlation was observed between ID of Pythium and damping-off. On the whole, the results seem to support the view of DiAmOND and Horsfall (1965) who claim that, only in exceptional cases is inoculum density of a pathogen directly correlated with the disease.

Many authors use transformations of disease percentages to obtain better correlations with ID of a pathogen (BAKER 1971, FERRISS 1982, Gilligan 1983). Bouhot and Joannes (1979) compared in a material of more than 600 soil samples four mathematical transformations of disease percentages. In $80-90 \%$, the log-log and the probit-log transformations proved the best. In the present investigation there was no overall improvement of correlations between ID and disease by the use of transformations, although in some cases this did happen (V). The material is, however, too small to draw any conclusions in this respect.

\subsubsection{Inoculum potential of Pythium}

\subsubsection{Concept}

According to Вочнот (1979), the system inoculum potential (IP) - disease is the most appropriate for Pythium to calculate the risk of obtaining disease.

The IP of a pathogen has been defined in various ways. According to DIAMOND and Horsfall (1965), it can be defined in a broad sense as the result of the action of the environment, the vigor of the pathogen to establish an infection, the susceptibility of the host and the amount of inoculum present. MARTINSON (1963) defines the term as a function of inoculum density or intensity, available nutrient and genetic capacity of the organism. According to Bочнот (1979), the number of successful infections obtained in optimum environmental conditions on a standard susceptible host is in practice the only valid measure of IP. For reliable and replicable results in the estimation of IP, the following criteria must be met (Вочнот 1979):

1) Select an indicator plant susceptible to the parasite.

2) Use the plant at its most sensitive period.

3) Apply the naturally infested soil sample to the most sensitive part of the plant.

4) Standardize the environmental conditions so that the inoculum potential constantly induces maximum disease.

5) Quantify the techniques by progressively diluting the soil sample.

6) Determine optimal conditions for the highest selectivity, sensitivity and rapidity of the technique.

The sensitivity of the bioassays can be increased by adding selective substrates to the soil to increase the mass of inoculum. Pythium spp., which are weak competitors against other microorganisms in soil (HENDRIX and CAmpbell 1973), can readily colonize introduced organic baits like corn (LiU and 
Vaughan 1965), papaya tissues (Trujillo and HINE 1965) or oats (YARWOOD 1966). Oat meal increased the sensitivity of detection of Pythium by at least hundredfold (Вочнот 1975 a). Furthermore, a quantification factor can be introduced. Bоuнот (1975 b) diluted the test soil with sterile soil and obtained a partial linear relationship between the dilution rate and the amount of disease in the indicator plants. He used the linear part of the curvilinear graph to calculate the IP of the soil. $\mathrm{He}$ calculated an inoculum potential unit $\left(\mathrm{IPU}_{50}\right)$, which is defined as the minimum quantity $(\mathrm{g})$ of test soil necessary to induce 50 $\%$ mortality in the plant population under standard experimental conditions.

\subsubsection{Applications}

The IP of Pythium was determined at the end (growing periods 7 and 8 ) of a glasshouse crop rotation experiment (V, Fig. 3). The experiment was set up on three soil types, i.e. peat, very fine sand and sandy clay. The variation in numbers of $\mathrm{IPU}_{50} / \mathrm{g}$ soil between growing periods and rotations was considerable, the values ranging from 0.2 to 16 . In all three soil types, rotations with a high sequence of cereals exhibited on average lower IP of Pythium than did continuously cultivated sugar beet which, however, had the highest IP in only one case. In peat and sandy clay rotations with the leguminous crop field bean caused great increases in the IP of Pythium. In the very fine sand, however, the highest IP were found in rotations with barley and grass (V, Fig. 3). Although ID and IP of Pythium are closely related ecological concepts they correlated poorly with each other $(\mathrm{V}$, Table 7).

To understand the variations in the results for ID and IP of Pythium and the mostly weak correlations between these and dampingoff of Pythium, one must also take the concept of competitive saprophytic ability (CSA) into consideration, although it was not estimated in this investigation (V). CSA is defined as the ability of phytopathogenic fungi to de- velop saprophytically in the soil, which can explain their multiplication and survival in the absence of a susceptible host. Furthermore, CSA may offer an explanation to the fluctuations in ID too (Вочнот 1979). For estimation of CSA the Cambridge method is frequently used (Butler 1953, LuKas 1955, DHINGRA et al. 1976). According to this method, calibrated fragments of dead plant tissues are placed in the soil to trap the fungus to be studied. Соок (1970) buried fresh or autoclaved wheat straws to study saprophytic colonization of Fusarium roseum $f$. $s p$. cerealis 'culmorum'. Вочнот (1980) used a simplified version of RoBERTSON's (1975) paper disc method to measure the CSA of Pythium.

Bоuнот (1979), referring to several investigations about ID and CSA in relation to disease, concluded that disease severity in the case of Pythium spp. and Rhizoctonia solani is much more correlated with CSA than with ID. This, however, is less evident for rootinhabiting fungi like $F$. oxysporum, Verticillium and Gaeumannomyces.

\subsubsection{Preceding crops}

Monocropping is common in Finnish sugar beet cultivation. This is thought to be one of the main reasons for the severe outbreaks of damping-off during the last decades.

The effect on damping-off of different preceding crops as compared to sugar beet monocropping was studied in pot experiments in the glasshouse (V). Short-term effects, that is 4-month cultivation of a breaking crop, showed that legumes on average tended to keep the level of damping-off unchanged or even to raise it as compared to continuously cultivated sugar beet. Graminous plants, especially cereals, on the other hand, had an opposite short-term effect, increasing emergence and the numbers of surviving sugar beet seedlings (V, Fig. 1). These effects of preceding crops are in agreement with CoONS and KOTILA (1935), Deems and Young (1956) and MumFORd (1968). ARndt and Behr (1973) found no general relation between black leg and crop 
rotation but infection by Pythium was, however, more harmful on plots with narrow rotations and high concentration of sugar beet.

The long-term effects of preceding crops were studied in a glasshouse experiment of eight growing periods. Preceding crops to sugar beet were field bean, barley and grass, only one crop in each rotation. The sequences of sugar beet varied between 14 and $86 \%$ (V, Table 2). The experiment lasted more than three years. During that time, the seasonal variations in climatological conditions like radiation, temperature and air humidity were considerable. At growing period 8 , beet monocropping showed a mean (of three soils) post-emergence damping-off percentage of $34.8 \%$ as compared to $14.0-28.0 \%$ for the rotations. In contrast to the short-term effect, the legume field bean decreased disease significantly, as did barley and grass, too. Calculated from growing period 8 , the correlation coefficient between percentage of sugar beet in rotation and percentage of postemergence damping-off was significant $\left(r=0.841^{* *}\right)$. This experiment also indicated that response to preceding crops may vary according to soil type.

The results indicate that the effect of preceding crop is much an effect on the pathogen Pythium, especially the immediate shortterm effect of the growing crop. Legumes, especially pea, had a disease increasing effect. Pea is often attacked by Pythium spp. (Robertson 1973, Ruokola 1979), which are related to those attacking sugar beet, suggesting that pea roots and root exudates can serve as suitable nutrients or energy sources also for Pythium species on sugar beet. It is a wellknown fact that root exudates affect mycelial growth and oospore germination (BRown and Kennedy 1966, Kraft and Erwin 1967, AGNIHOTRI and VAARTAJA 1968) as well as zoospore movement (ROYLE and HiCKMAN 1964, Spencer and Cooper 1967, Kraft and Erwin 1968, Chang-Ho 1970) of Pythium spp. In the case of cereals as preceding crops, on the other hand, the composition of root exudates may be unfavourable for Pythium.

The long-term effects of preceding crops during several growing periods seem to differ from the immediate effect (V). Presumably, there will be an effect over time on the saprophytic microflora, on the soil fauna and on other soil components. The results presented here are not directly comparable to field conditions, because the influence of winter, for example, cannot be taken into account in glasshouse experiments.

\section{Disease forecasting}

Introductory experiments were carried out to study the possibilities of forecasting disease outbreaks in the field. Soil samples collected from sugar beet fields in the spring and autumn 1980 and 1981 were taken to a glasshouse, where the percentage of damping-off was determined. This was then compared with the percentage of disease in the field (III, Fig. 2, Table 3).

Soil collected from 36 fields in spring 1980 gave damping-off incidence of $21.8 \%$ and $32.5 \%$ in the glasshouse at $8^{\circ} \mathrm{C}$ and $18^{\circ} \mathrm{C}$, respectively, while soil collected from the same fields in autumn 1980 gave disease incidences of $31.3 \%$ and $61.6 \%$, respectively. The disease incidence in the glasshouse usually correlated rather poorly with that in the field, but was on average somewhat better for samples collected in autumn (especially in high glasshouse temperature) than in spring (III).

It was concluded that the possibilities of forecasting disease outbreaks in this way are rather limited, which supports the works of BARTELS and WinNer (1971) who studied the Pythium infection of beet side roots with a view of making prognosis of damage by methods similar to those used in this study. When the temperature factor is taken into account, a negative prognosis using the following criteria, however, should be possible:

- Sugar beet seedlings are grown under glass at a high temperature in soil collected from the field in autumn. 
- If no disease occurs in the glasshouse, the risk of outbreaks in the field is minimal.

- If heavy outbreaks occur in the glasshouse, there is a high potential risk of severe attacks also in the field. However, the disease may remain at a low level if conditions unfavourable for development of the disease prevail.

\section{Disease control}

In the control of damping-off of sugar beet one must distinguish between soil borne and seed borne damping-off.

In controlling seed borne damping-off of sugar beet, seed dressings with mercurial compounds or thiram have been predominating (Gates and Hull 1954, Gates 1959, Nölle 1960, LÜDECKE and WinNER 1963, LiNNASALMI 1970, MÖLlerström 1974, Flori et al. 1985, MAude and Bambridge 1985). In England, BYFORD (1972) reported that Phoma betae damaged only few seedlings in commercial crops, although infection in sugar beet seed clusters were $20-62 \%$ in $1958-1970$. Steeping of the seeds in ethyl mercuric phosphate controlled the fungus. Maneb and mancozeb have also been reported to control seed borne damping-off of sugar beet (DARPOUx et al. 1966, Косн 1979, Hrubesh and Wieser 1978).

Soil borne damping-off of sugar beet is more difficult to control than the seed borne type. Despite this, treatment of seeds with fungicides such as iprodione, metalaxyl, hymexazol (Dunning and Heijbroek 1981), fenaminosulf (LeACH and Hills 1960, SCHultze and Bohle 1976), propamocarb and phosetyl-Al (JAMART et al. 1983) also affects soil borne Pythium damping-off.

In Finland, the soil borne pathogens Pythium debaryanum and Fusarium spp. are predominating in damping-off of sugar beet, while Phoma betae plays a minor role (I). Protective fungicides such as mercurial compounds or thiram had an insufficient effect on the soil borne damping-off (II). In the control experiments, therefore, the main stress has been on testing fungicides efficient especially against Pythium, which is the main microorganism causing seedling death at early stages.

A range of fungicides were tested as seed dressors. Moreover, intensified control such as seed treatment combined with row spraying at seedling emergence or seed furrow application was also studied. Biological control agents were tested alongside with the chemical compounds (II).

The report in 1966 of carboxamide that moved systemically in a plant and suppressed fungal activity within the plant initiated the era of systemic fungicides (FRY 1982), which have created new possibilities for control of soil borne pathogens. In this study, the systemic fungicide propamocarb, which is efficient against Pythium species (ANON. 1978) proved efficient against soil borne dampingoff in pot experiments but usually not under field conditions (II). This may be a consequence of temperature or $\mathrm{pH}$. In the pot experiment the effect of the fungicide was good at low temperature but negligible at high temperature. KAARS SIJPESTEIJN and coworkers (1974), working with prothiocarb, which is closely related to propamocarb, found a high fungitoxicity of prothiocarb at $\mathrm{pH} 7$ but negligible at $\mathrm{pH}$ 5.3.

With regard to the effect of temperature, two glasshouse experiments at $8^{\circ} \mathrm{C}$ and $18^{\circ} \mathrm{C}$ showed the response to seed dressings to increase with decreasing temperature, a fact that is in agreement with the findings of Gates and Hull (1954). At $8^{\circ} \mathrm{C}$ the treatment of seeds even with mercurial compounds was somewhat effective against soil borne damping-off, but at $18^{\circ} \mathrm{C}$ the effect was negligible. Under field conditions, however, only hymexazol and especially hymexazol + thiram proved effective seed dressors (II, Tables 7-12), a finding which is in agreement with KocH (1979). Seed treatment with these fungicides gave good protection of the seedlings against damping-off up to about two weeks after emergence. Thereafter damping-off did occur, but the disease 
was mostly of the chronic type and not of the dangerous type. Although hymexazol alone had a negligible effect on damping-off in some experiments (II, Tables 9 and 10), the combination hymexazol + thiram had always a significant disease decreasing effect. Hymexazol increased in different experiments the final number of beet roots per hectare in autumn by $7100-31200$. The seed treatment hymexazol + thiram increased sugar beet yield in field experiments on average by $5-10 \%$ (II).

Hymexazol is reported to be effective against a range of soil borne diseases, especially those caused by Pythium, Fusarium and Aphanomyces (AnON. 1971). Hymexazol is not only an effective fungicide against these fungi, but also a plant growth promotor (KuKalenKo and Volodovich 1979). Both pot and field experiments showed higher amounts clearly to improve the effect of hymexazol. The optimum would be about $10 \mathrm{~g}$ a.i. $/ \mathrm{kg}$ seed combined with thiram $4 \mathrm{~g}$. The use of thiram together with hymexazol improved the health of beet stands more than did hymexazol alone (II). The same was observed by HRUBESH and WIESER (1978) who also recommend mancozeb in this respect.

Naked sugar beet seed was used in most experiments in this study. However, two experiments (II, Tables 11 and 12) showed that disease control may be even better by the use of pelleted seed, a fact also stressed by PANDAY and Agnimotri (1985). However, the use of the fungicides in pelleted seed gave smaller yield increases than did fungicidal treatment of naked seed.

Some investigators mention certain soil-row spray treatments to be superior to standard seed treatments (Hills and LEACH 1952, Gerhold 1956, Schultze and Bohle 1976, LinNASALMI 1970). In this study, spraying with hymexazol and thiram at seedling emergence in a $5 \mathrm{~cm}$ broad band using high amounts of water (up to $20000 \mathrm{l} /$ net hectare) gave almost a $100 \%$ control of the disease (II, Table 10). However, the efficient fungicidal concentration used, $0.5 \%$, means a total amount of 7 and $3 \mathrm{~kg}$ a.i. per hectare of hymexazol and thiram, respectively, amounts which are not economically profitable to use. Moreover, the favourable effect of such bandspraying on the yield of sugar beet in comparison with seed dressing alone was very small, except on some localities with extremely severe outbreaks of the disease. The application of the fungicide, using small amounts, to the seed furrow in connection with sowing, gave good results, but this method needs further technical development (II, Tables 3 and 14).

Pythium oligandrum Drechs., originally described by DRECHSLER (1946), was tested as biological control agent. The fungus was applied in a seed treatment in the form of a powder biopreparation containing oospores. Although effects of $P$. oligandrum comparable to those of fungicides such as thiram (VEselý 1978, 1979) or fenaminosulf (MARTIN and HANCOCK 1987) have been reported, no evident protective effect of the hyperparasite was found in this study (II, Table 4, 9).

In field experiments, $P$. oligandrum even lowered the yield of sugar beet by about 15 $\%$ as compared to yield from untreated sugar beet seeds. This would indicate that the fungus acted as a pathogen on sugar beet and not as a hyperparasite on P. debaryanum. According to Veselý (1977 a), P. oligandrum is itself a weak facultative parasite on sugar beet seedlings, but the losses caused by it are in the order of a few percents. Veselý and HeJdANEK (1984) also point out the importance of a relatively low temperature from seed germination to emergence and during the cotyledon stage to get the highest benefit of the biopreparation.

Another species of Pythium, P. nunn Lifshitz, Stanghellini \& Baker, (Lifshitz et al. 1984 a) has also been used for biological control of Pythium damping-off (LifSHitz et al. 1984 b, PAUlitz and BAKer 1987). The possible role of different genera of bacteria in the biological control of Pythium has been discussed as well (BroAdBent et al. 1971, NeLSON et al. 1986, ELAD and CHET 1987). 


\section{References}

Afanasiev, M.M. \& Morris, H.E. 1942. Control of seedling diseases of sugar beets in Montana. Phytopath. 32: 477-486.

- \& CARLson, W.E. 1943. The relation of phosphorus and nitrogen ratio to the amount of seedling diseases of sugar beets. Proc. Amer. Soc. Sugar Beet Technol. 1942: 407-411.

Agnihotri, V.P. \& Vaartaja, O. 1968. Seed exudates from Pinus resinosa and their effects on growth and zoospore germination of Pythium afertile. Can. J. Bot. 46: 1135-1141.

Angell, H.R. 1954. Partial segregation of bacteria and isolation of Pythium from the coarser soil fractions. Austr. J. Agric. Res. 5: 702-705.

Anon, 1971. F-319. Soil Fungicide. Sankyo Co, LTD. 34 pp. Tokyo.

-, 1978. Previcur N. Fungizid. 1. Mitteilung Schering AG. 29 pp. Berlin.

Arndt, R. \& Berr, L. 1973. Einfluss von Fruchtfolge and Anbaukonzentration auf die Auflaufkrankheiten der Zuckerrübe. Nachr.bl. Pfl.schutzd. DDR 27: 53-57.

Arrhenius, O. 1924. Försök till bekämpande av betrotbrand. II. Kalkningens och markreaktionens inflytande pá sjuka och friska betors utveckling. Medd. Centr.anst. Förs.văs. Jordbr.omr. Avd. lantbr.bot. 31. $15 \mathrm{pp}$. Stockholm.

BAKER, R. 1971. Analyses involving inoculum density of soilborne plant pathogens in epidemiology. Phytopath. 61: $1280-1292$.

BARtels, G. \& Winner, C. 1971. Untersuchungen über den Einfluss wurzelinfizierender Pilze auf Entwicklung, Ertrag und Qualităt der Zuckerrübe unter dem Aspekt einer Schadensprognose. Zucker 24: 315-355.

BArton, R. 1958. Occurrence and establishment of Pythi$u m$ in soils. Trans. Brit. Mycol. Soc. 41: 207-222.

Benada, J., SĚdivý, J. \& Špačé, J. 1987. Atlas of diseases and pests in beet. Elsevier. 272 pp. Amsterdam-Oxford-New York-Tokyo.

Buorlıng, K. 1945. Undersökningar rörande Phoma betae (Oud.) Fr. med särskild hănsyn till en av svampen orsakad stjälkröta på betfröplantor. Stat. Växtskyddsanst. Medd. 44: 1-96.

Вочнот, D. 1975 a. Recherches sur l'écologie des champignons parasites dans le sol. V. Une technique sélective d'estimation du potentiel infectieux des sols, terreaux et substrats infestés par Pythium sp., études qualitatives Ann. Phytopath. 7: 9-18.

- 1975 b. Recherches sur l'écologie des champignons parasites dans le sol. VII. Quantification de la tech- nique d'estimation du potentiel infectieux des sols, terreaux et substrats infestés par Pythium sp. Ann. Phytopath. 7: 147-154.

- 1979. Estimation of inoculum density and inoculum potential: Techniques and their value for disease prediction. In "Soil borne plant pathogens", eds SCHIPPERS B. \& Gams, W., Academic Press, New York, 686 pp.

- 1980. Le potentiel infectieux des sols (soil infectivity). Un concept, un modèle pour sa mesure, quelques applications. These de doctorat ès sciences. $143 \mathrm{pp}$. Université de Nancy.

- \& JoAnNes, H. 1979. Écologie des champignons parasites dans le sol. -IX. Mesures du potentiel infectieux des sols naturellement infestés de Pythium sp. Soil Biol. Biochem. 11: 417-429.

Boyd, A.E.W. 1966. Sugar beet strangles. Edin. School. Agric. Tech. Bull. 26: 1-42.

Broadbent, P. Baker, K.F. \& Waterworth, Y. 1971. Bacteria and actinomycetes antagonistic to fungal pathogens in Australian soils. Austr. J. Biol. Sci. 24: 925-944.

Brown, G.E. \& Kennedy, B.W. 1966. Effect of oxygen concentration on Pythium seed rot of soybean. Phytopath. 56: 407-411.

Brummer, V. 1960. Sokerijuurikkaan muokkaus- ja kylvőaikakokeiden tuloksia. Maatalous 53: 246-247.

Вuснноттz, W.F. 1938. Factors influencing the pathogenicity of Pythium debaryanum on sugar beet seedlings. Phytopath. 28: 448-475.

BUTLER, F.C. 1953. Saprophytic behaviour of some cereal root rot fungi. I. Saprophytic colonization of wheat straw. Ann. Appl. Biol. 40; 484-497.

Butler, E.J. \& Jones, S.G. 1961. Plant pathology. 979 pp. London.

BYFoRd, W.J. 1972. The incidence of sugar beet seedling diseases and effects of seed treatment in England. PI. Path. 21: 16-19.

- \& Stamps, D.J. 1975. Aphanomyces cochlioides in England. Trans. Brit. Mycol. Soc. 65: 157-162.

Bottcher, I. \& Behr, L. 1980. Pilze der Gattung Pythium als Wurzelbranderreger der Zuckerrübe. Arch. Phytopath. Pfl.schutz 16: 95-102.

Chang-Ho, Y. 1970. The effect of pea root exudate on the germination of Pythium aphanidermatum zoospore cysts. Can. J. Bot. 48: 1501-1514.

Соoк, R. J. 1970. Factors affecting saprophytic colonization of wheat straw by Fusarium roseum f.sp. cerealis 'culmorum'. Phytopath. 60. 1672-1676.

Coons, G.H. \& Stewart, D. 1927. Prevention of seedling diseases of sugar beets. Phytopath. 17: 259-296. 
— \& Kotila, J.E. 1935. Influence of preceding crops on damping-off of sugar beets. Papers presented at the twentysixth annual meeting of the American Phytopathological Society. Abs. in Phytopath. 25: 13.

—, - — Bockstahler, H.W. 1948. Black root of sugar beet and possibilities for its control. Proc. Amer. Soc. Sugar Beet Technol. 1946: 364-380.

Darpoux, H., Lebrun, A. \& De la Tullaye, B. 1966. Efficacité des fongicides dans la désinfectión des semences de betterave. J. Intern. Inst. Sugar Beet Res. 1: $67-83$.

Deems, R.E. \& Young, H.C. 1956. Black root of sugar beets as influenced by various cropping sequences and their associated mycofloras. J. Amer. Sugar beet Technol. 9: $32-43$.

Dhingra, O.D., Tenne, F.D. \& Sinclair, J.B. 1976. Method for the determination of competitive saprophytic colonization of soil fungi. Trans. Brit. Mycol. Soc. 66: 447-456.

Diamond, A.E. \& Horsfall, J.G. 1965. The theory of inoculum. In "Ecology of soil-borne plant pathogens", eds Baker, K.F. \& Snyder, W.C., University of California Press, 522 pp, Berkeley, Los Angeles.

Domsch, K.H., Gams, W. \& Anderson, T.H. 1980. Compendium of soil fungi. Volume 1. Academic Press. 859 pp. London.

Doran, W.L. 1946. Control of damping off by a delay in first watering after seedling. Report of the 1946 annual meeting of the New England Division of the American Phytopathological Society. Abs. in Phytopath. 36: 679-680.

Drechsler, C. 1946. Several species of Pythium peculiar in their sexual development. Phytopath. 36: 781-864.

DunNing, R.A. 1972. Sugar beet pest and disease incidence and damage, and pesticide usage. Report of an I.I.R.B. enquiry. J. Intern. Inst. Sugar Beet Res. 6: $19-34$.

- \& Heisbroek. W. 1981. Improved plant establishment through better control of pest and disease damage. Proc. of I.I.R.B. 44th winter congr.: 37-58.

ELAD, Y. \& CHET, I. 1987. Possible role of competition for nutrients in biocontrol of Pythium damping-off by bacteria. Phytopath. 77: 190-195.

FerRISS, R.S. 1982. Relationship of infection and damping-off of soybean to inoculum density of Pythium ultimum. Phytopath. 72: 1397-1403.

Flori, P., Roberti, R. \& InNocenti, G. 1985. Osservazioni sulla biologia di Phoma betae (Oud.) Frank ed interventi di lotta. Difesa delle Piante 8: 355-370.

FrY, W.E. 1982. Principles of plant disease management. Academic Press. 378 pp. New York London.

GATES, L.F. 1959. Further experiments on black-leg disease of sugar-beet seedlings. Ann. Appl. Biol. 47: $502-510$.

— \& Hull, R. 1954. Experiments on black leg disease of sugar-beet seedlings. Ann. Appl. Biol. 41: 541-561. Gerhold, N.R. 1956. Sugar beet diseases and their control. Ia St. Coll. J. Sci. 30: 362.

Gilligan, C.A. 1983. Modeling of soilborne pathogens. Ann. Rev. Phytopath. 21: 45-64.

Gram, E. 1927. Afsvampningsundersøgelser. II. Forsøg med runkelroe- og sukkerroefrø 1920-1925. Statens Forsøgsvirksomhed i Plantekultur. Ber. 197. 66 pp.

Greeves, T.N. \& Muskett, A.E. 1936. A temperature study of Pythium attack on swede seedlings. Ann. Appl. Biol. 23: 264-270.

GreIs, H. 1940. Ein Wurzelbrand an der Zuckerrübe, verursacht durch Alternaria tenuis. Phytopath. Z. 13: 196-206.

Griffin, D.M. 1958. Influence of $\mathrm{pH}$ on the incidence of damping-off. Trans. Brit. Mycol. Soc. 41: 483-490.

- 1972. Ecology of soil fungi. 193 pp. Syracuse University Press.

GuY, S.O. \& BAKER, R. 1979. Inoculum potential in relation to biological control of Fusarium wilt of peas. Phytopath. 67: 72-78.

Haskins, R.H. 1965. Sterols and temperature tolerance in the genus Pythium. Science 150: 1615-1616.

Heidel, W. \& Schultze, R. 1984. Erste Ergebnisse von Feld- und Laboruntersuchungen über die Erreger des Wurzelbrandes bei Zuckerrüben auf Diluvialstandorten im Norden der DDR. Nachr.bl. Pfl.schutz DDR 38: $33-37$.

Helminen, A. 1979-1987. Meteorologiska institutet. Månadsöversikt över Finlands klimat. Maj-juni. Ảrg. $73-81$.

Hendrix, F.F. \& Campbell, W.A. 1973. Pythiums as plant pathogens. Ann. Rev. Phytopath. 11: 77-98.

Hills, F.J. \& Leach, L.D. 1952. The effect of certain soil-row treatments on damping-off of sugar beet seedlings caused by specific fungi. Proc. Amer. Soc. Sugar Beet Technol. 1952: 549-553.

Hodges, F.A. 1936. Fungi of sugar beets. Phytopath. 26: $550-563$.

Hoppe, P.E. 1966. Pythium species still viable after 12 years in air-dried muck soil. Phytopath. 56: 1411.

Hrubesch, W. \& Wieser, F. 1978. Saatgutbeizung von pilliertem Zuckerrübensaatgut. Zuckerind. 103: 400-407.

JACKS, H. 1951. The efficiency of chemical treatments of vegetable seeds against seed-borne and soil-borne organisms. Ann. Appl. Biol. 38: 135-168.

Jamart, G., Kamoen, O. \& Van Vaerenbergh, J. 1983. Chemical control of damping-off of seedling bedding plants incited by Pythium species. Med. Fac. Landbouww. Rijksuniv. Gent 48: 775-782.

Kaars Sijpesteiun, A., Kerkenaar, A. \& Overeem, J.C. 1974. Observations on selectivity and mode of action of prothiocarb (SN 41703). Med. Fac. Landbouww. Gent 39: 1027-1034.

Косн, F. 1979. Zehnjährige Feldversuche zur Frage der Fungizidbehandlung von nacktem und pilliertem Zuck- 
errübensaatgut. Zuckerind. 104: 131-134.

Kraft, J.M. \& Erwin, D.C. 1967. Stimulation of Pythium aphanidermatum by exudates from mung bean seeds. Phytopath. 57: 866-868.

- 1968. Effects of inoculum substrate and density on the virulence of Pythium aphanidermatum to mung bean seedlings. Phytopath. 58: 1427-1428.

Kukalenko S.S. \& Volodoovich, S.D. 1979. New systemic fungicides from foreign countries. All-Union Scientific Research Institute for Chemical Agents for Plant Protection under Ministery of Chemical Industry, U.S.S.R. Khimijav Seljskom Khozjajstve 1979. 19 pp.

KOHNEL, W. 1978. Untersuchungen zur Verbreitung bodenbürtigen Wurzelbranderreger der Zuckerrübe. Arch. Phytopath. Pfl.schutz 14: 109-114.

LeACH, L.D. \& Hil.s, F.J. 1960. Combinations of specific fungicides for sugar beet seed treatment. J. Amer. Soc. Sugar Beet Technol. 11: 75-83.

- \& Macdonald, J.D. 1976. Seed-borne Phoma betae as influenced by area of sugarbeet production, seed processing and fungicidal seed treatments. J. Amer. Soc. Sugar Beet Technol. 19: 4-15.

Lifshitz, R. \& Hancock, J.G. 1983. Saprophytic development of Pythium ultimum in soil as a function of water matric potential and temperature. Phytopath. 73: 257-261.

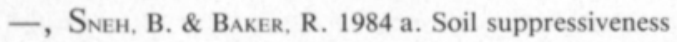
to a plant pathogenic Pythium species. Phytopath. 74: 1054-1061.

-, Stanghellini, M. \& Baker, R. 1984 b. A new species of Pythium isolated from soil in Colorado. Mycotaxon 20: 373-379.

LiKaIS, R. 1948. Einfluss des Bodens und antagonistischer Bodenmikroben auf den Parasitismus von Pythium de Baryanum. Arch. Mikrobiol. 18: 49-100.

Linnasalmi, A. 1952. Damping-off on herbaceous vegetables and ornamental plants grown under glass in Finland. Ann. Bot. Soc. 'Vanamo' 26: 1-120.

Linnasalmi, A. 1970. Sokerijuurikkaan taimipolte ja sen torjunta Suomessa. Ann. Agric. Fenn. 9: 296-303.

Liu S. \& Vaughan, E.K. 1965. Control of Pythium infection in table beet seedlings by antagonistic microorganisms. Phytopath. 55: 986-989.

LuKas, R.L. 1955. A comparative study of Ophiobolus graminis and Fusarium culmorum in saprophytic colonization of wheat straw. Ann. Appl. Biol. 43: 134-143.

Lumsden, R.D. \& Ayers, W.A. 1975. Influence of soil environment on the germinability of constitutively dormant oospores of Pythium ultimum. Phytopath. 65: $1101-1107$.

LODECKE, H. \& WinNer, C. 1963. Die Wirkung handelsüblicher Beizmittel und insektizider Saatgutpuder auf den feld-aufgang in Versuchen mit segmentiertmonogermen Zuckerrübensamen in Westdeutschland. Zucker 16: 644-649.
Maloy, O.D. \& Alexander, M. 1958. The "most probable number" method for estimating populations of plant pathogenic organisms in the soil. Phytopath. 48: $126-128$.

MARTin, J.P. 1950. Use of acid, rose bengal and streptomycin in the plate method for estimating soil fungi. Soil Sci. 69: 215-232.

Martin, F.N. \& Hancock, J.G. 1987. The use of Pythium oligandrum for biological control of preemergence damping-off caused by $P$. ultimum. Phytopath. 77: 1013-1020.

MARTInson, C.A. 1963. Inoculum potential relationships of Rhizoctonia solani measured with soil microbiological sampling tubes. Phytopath. 53: 634-638.

Maude, R.B. \& Bambridge, J.M. 1985. Effects of seed treatment and storage on the incidence of Phoma betae and the viability of infected red beet seeds. Pl. Path. 34: $435-437$.

Mc KaY, R. 1952. Sugar beet diseases. I. Fungus diseases. Irish Sugar Company LTD. 77 pp. Dublin.

Meurs, A. 1928. Ein neuer Wurzelbranderreger der Zucker- und Futterrüben. Phytopath. Z. 1: 111-116.

MikKelsen, N.U. 1982. Rodbrand og vaeltesyge i bederoer. Botanisk Afdelning, Plantevaernscentret, Danmark. 33 pp. Lyngby.

Middleton, J.T. 1943. The taxonomy, host range and geographic distribution of the genus Pythium. Mem. Torrey Bot. Club 20:7-171.

MitChelL, D.J. 1978. Relationships of inoculum levels of several soilborne species of Phytophthora and Pythium to infection of several hosts. Phytopath. 68: $1754-1759$.

Mumford, D.L. 1968. Evaluating soil samples for fungus pathogens to sugarbeet seedlings. J. Amer. Soc. Sugar Beet Technol. 15: 255-258.

Mólerström, G. 1974. Odlingsteknik och pesticidanvăndning inom sockerbetsodlingen. Medd. St. Växtsk.anst. 16 (nr 160): 29-50.

- \& Klinteberg, H.B. 1964. Black leg in sugarbeets. Socker Handl. II 19: 1-15.

Neison, E.B., Chao, W.-L., Norton, J.M., Nash, G.T. \& HaRMAN, G.E. 1986. Attachment of Enterobacter cloacae to hyphae of Pythium ultimum: Possible role in the biological control of Pythium preemergence damping-off. Phytopath. 76: 327-335.

Nolle, H.-H. 1960. Über den Wurzelbrand der Zuckerrübe und seine Bekämpfung. Phytopath. Z. 37: 161-200.

Panday, S. \& Agnihotri, U.P. 1985. Efficacy of fungitoxicants in controlling damping-off of sugarbeet seedlings caused by Pythium ultimum. Ind. J. Pl. Path. 3: 83-88.

Papavizas, G.C. \& Ayers, W.A. 1976. Aphanomyces species and their root diseases in pea and sugarbeet. A review. U.S. Dep. Agric. Tech. Bull. 1485. 158 pp. Washington DC.

PAulitz, T.C. \& BAKer, R. 1987. Biological control of 
Pythium damping-off of cucumbers with Pythium nunn: Population dynamics and disease suppression. Phytopath. 77: 335-340.

PElo, M. 1987. Mitä maanäytteet kertovat. Juurikas 7(2): 10-13.

Peshel, R. 1969. Das Auftreten der wichtigsten Krankheiten und Schädlinge der landwirtsschaftliche und gärtnerischen Kulturpflanzen im Jahre 1968 im Bereich der Deutschen Demokratischen Republik. Nachr.bl. deut. Pfl.-schutzd. 23: 141-170.

Pool, V.W. \& Mc Kay, M.B. 1915. Phoma betae on the leaves of sugar beet. J. Agric. Res. 4: 169-177.

RAININKo, K. \& Vestberg, M. 1981. Sokerijuurikkaan taimipolte ja sen torjuntamahdollisuudet. Maataloustieteen päivät 1981. Suomen maataloustieteellisen seuran tiedote no 1: 38-41.

RAsmussen, A.N. 1967. Afsvampning av bederoefrø. Tidskr. Pl.avl 71: 345-354.

Remy, E. 1950. Über niedere Bodenphycomyceten. Arch. Microbiol. 14: 212-239.

Ricci, P., Toribio, J.A. \& Messiaen, C.M. 1976. La dynamique des populations de Pythium dans les sols Maraîchers de Guadeloupe. I. Méthodes d'étude. Ann. Phytopath. 8: 51-63.

Robertson, G.I. 1973. Pathogenicity of Pythium spp. to seeds and seedling roots. N.Z. J. Agric. Res. 16. $367-372$.

- 1975. A paper disc technique for"the recovery of Pythium spp. from soil or water. N.Z. J. Agric. Res. 18: 409-410.

Roth, L.F. \& Riker, A.J. 1943. Influence of temperature, moisture and soil reaction on the damping-off of red pine seedlings by Pythium and Rhizoctonia. J. Agric. Res. 67: 273-293.

Rovle, D.J. \& Hickman, C.J. 1964. Analysis of factors governing in vitro accumulation of zoospores of Pythium aphanidermatum on roots. 2. Substances causing response. Can. J. Mikrobiol. 10: 201-219.

Ruокоц., A.-L. 1979. II. Fungus diseases of pea seeds and stands in Finland. Acta Agric. Scand. 29: 225-233.

Russell, E.W. 1961. Soil conditions and plant growth. 9th ed. 688 pp. London.

SChmitthenner, A.F. 1962. Isolation of Pythium from soil particles. Phytopath. 52: 1133-1138.

SCHOLlimeYer, M.-L. 1980. "Strangles" - eine im Jahre 1979 aufgetretene Erkrankung an Zuckerrüben. Nahr.bl. Pfl.-schutz DDR 34: 252-253.

SChultze, Е. \& Bohle, Н. 1976. Zuckerrübenproduktion. Landwirtsschaftliche Bodennutzung mit hoher Rendite. 206 pp. Berlin und Hamburg.

SChÃufele, W.R. \& Winner, C. 1972. Zur Verhütung und Bekämpfung pilzlicher Wurzelkrankheiten der jungen Zuckerrübe. Zucker 25: 153-156.

SHEN, C.I. 1940. Soil conditions and the Fusarium culmorum seedling blight of wheat. Ann. Appl. Biol. 27: $323-329$.
SPencer, J.A. \& CoOper, W.E. 1967. Pathogenesis of cotton (Gossypium hirsutum) by Pythium species: Zoospore and mycelium attraction and infectivity. Phytopath. 57: 1332-1338.

Stanghellini, M.E. \& Hancock, J.G. 1970. A quantitative method for the isolation of Pythium ultimum from soil. Phytopath. 60: 551-552.

Sverrisson, H. 1979. Pythium-slaegtens biologi og plantepatologiske betydning. Licentiatstudium. Den $\mathrm{Kgl}$. Veterinaer-og Landbohøjskole. Plantepatologisk Afdelning. 179 pp. København.

Takahashi, M., Tanaka, Y., Ichitani, T. \& Alicbusan. R.V. 1972. Ecologic and taxonomic studies of Pythi$u m$ as pathogenic soil fungi. X. Several Pythium species causing damping-off of sugar beet seedlings. Ann. Phytopath. Soc. Jap. 38: 306-312.

Tíl., B.B. 1968. Occurrence of Pythium aphanidermatum on table beets in British Columbia. Can. Pl. Dis. Surv, $48: 37$.

Trujillo, E.E. \& Hine, R.B. 1965. The role of papaya residues in papaya root rot caused by Pythium aphanidermatum and Phytophthora parasitica. Phytopath. 55: 1293-1298.

UrBanOviCH, L. 1965. Zgorzel naczyniowa sievek Buraka cucrovego. (Black root of sugar beet seedlings). Gaz. Cukr. 73: 38-39.

Van Bruggen, A.H.C., Whalen, C.H. \& Arneson, P.A. 1986. Effects of inoculum level of Rhizoctonia solani on emergence, plant development and yield of dry beans. Phytopath. 76: 869-873.

Van Der Plaats-Niterink, A.J. 1981. Monograph of the genus Pythium. Stud. Mycol. no 21, 237 pp.

VESELY. D. 1976. The occurrence of the fungi of the genus Fusarium on sugar-beet seeds, in the rhizosphere and tissues of plants attacked by black leg. Ochr. Rostl. 12: 259-266.

- 1977 a. Potential biological control of Damping-off pathogens in emerging sugar beet by Pythium oligandrum Drechsler. Phytopath. Z. 90: 113-115.

- 1977 b. Pilze der Gattung Alternaria Nees ex Wallr., die am Wurzelbrand der Zuckerrüben beteiligt sind. Česká Mykol. 31: 100-107.

- 1978. Biological protection of emerging sugar-beet against damping-off established by mycoparasitism in non-sterilized soil. Zbl. Bakt. II. Abt. 133: 436-443.

- 1979. Ochranný efekt v rhizosfére cucrovky introdukcí mycelia Pythium oligandrum Drechsler. (The protective effect of the introduction of the mycelium of Pythium oligandrum Drechsler into the rhizosphere of sugar beet). Ochr. Rostl. 15: 53-56.

— \& Hejdanek, S. 1984. Microbial relations of Pythium oligandrum and problems in the use of this organism for the biological control of damping-off in sugar-beet. Zbl. Mikrobiol. 139: 257-265.

WARCUP, J.H. 1950. The soil-plate method for isolation of fungi from soil. Nature 166: 117-118.

WARREN, J.R. 1948. A study of the sugar beet seedling 
disease in Ohio. Phytopath. 38: 883-892.

W aterhouse, G.M. 1967. Key to Pythium Pringsheim. Commonw. Mycol. Inst. Mycol. Pap. 109. 15 pp. Kew.

YALE, J. \& VAUGhan, E. 1962. Effects of mineral fertilizers on damping-off of table beets. Phytopath. 52: $1285-1287$.
YARwood, C.E. 1966. Detection of Pythium in soil. PI. Dis. Rep. 50: 791-792.

YounG, H.C. 1943. Fertilizers in relation to the incidence of black leg. Sugar Beet J. 8: 212-219.

Zhukova, K.P. 1953. The effect of the acidity and moisture content of the soil on the infection of sugar beet seedlings by root rot agents (Pythium and Phoma). Rev. Appl. Mycol. 32: 4. 


\section{REFERAT}

Rotbrand är sedan gammalt en välkänd sjukdom på sockerbeta. Dả sockerbetsodlingen på 1970-talet rationaliserades och odlarna började så i så gott som färdiga bestånd ökade dock sjukdomens betydelse. Man hade ej mera råd att förlora plantor p.g.a. rotbrand.

Skördeförlusterna orsakade av rotbrand var vissa âr på 1970-talet ansenliga, uppskattningsvis $6-8 \%$. Behovet att fả sjukdomen under kontroll var därför stort.

Denna rotbrandsundersökning inleddes 1979 som samprojekt mellan institutionen för växtpatologi vid Helsingfors universitet och Centralen för Sockerbetsodling i Bjärnå. Från och med år 1985 ôverflyttades projektets växtpatologiska undersőkningar frân Helsingfors universitet till Mellersta Finlands forskningsstation vid Lantbrukets forskningscentral, Laukas.

Målet för undersökningen har varit att identifiera sjukdomsalstrarna, studera faktorer med inverkan pá sjukdomen samt att finna văgar för bekämpning av sjukdomen. Speciell vikt har varit fästad vid den viktigaste sjukdomsalstraren, svampen Pythium debaryanum.

Rotbranden kan under finländska förhållanden indelas i två faser, nämligen en fas då plantorna dör och en kronisk fas. Den första fasen börjar i och med frögroningen och fortsătter över uppkomststadiet fram till slutet av hjärtbladsstadiet. Denna fas innefattar ăven underjordisk rotbrand, vilken dock inte förekommer i någon större utsträckning i Finland. Plantorna har vanligtvis god uppkomst och sjukdomsangreppet sătter in ca 1 vecka efter uppkomsten. Plantorna erháller då en för sjukdomen typisk insnörning av rothalsen. Ofta breder det skadade området åven ut sig nerát till roten och uppât till hjärtbladens bas. Angripna plantor vissnar snabbt ner och dör, t.o.m. inom 1-2 dygn efter angreppets början. Den marklevande svampen Pythium debaryanum är den dominerande rotbrandsalstraren på detta stadium. Svampen utgjorde $53.9 \%$ av samtliga rotbrandssvampar isolerade under åren 1979-1986. Den årliga variationen var dock ansenlig, 18.3-90.1\%. Av övriga isolerade svampar pá tidigt plantstadium förekom arter av marklevande Fusarium i medeltal $28.3 \%(5.0-58.5 \%)$, medan den fröburna rotbrandspatogenen Phoma betae's andel var endast 1.2 $\%(0-4 \%)$.

Då betplantorna insjuknar på örtbladsstadiet överlever de ofta sjukdomen trots att roten blir trådaktigt tunn och svart. På hösten vid betupptagningen kan försommarens rotbrand ännu märkas som missformade betor med urgröpningar på rothalsen. Fusarium är de allmännast isolerade svamparna pá kroniskt rotbrandsstadium. Deras andel utgjorde $49.4 \%(36.1-81.0 \%)$ av samtliga isolerade svampar i förhållande till $23.9 \%(2.9-37.8)$ för $P$. debaryanum. Phoma betae förekom i ungefär samma utstrăckning som på hjărtbladsstadiet.

Ett mångfald av försök har visat att rotbrandsangreppen blir speciellt omfattande vid hŏga temperaturer. I praktiken kan man ofta mărka mycket kraftiga angrepp efter perioder av höga temperaturer under hjärtbladsstadiet eller tidigt örtbladsstadium. Detta är troligen en verkan riktad speciellt på Pythium-svampen, vilken har kraftigt ökad patogenitet vid höga temperaturer.

Sockerbeta odlas i Finland ofta som monokultur, vilket anses vara en bidragande orsak till den omfattande förekomsten av rotbrand. Olika förfrukters möjligtvis rotbrandsdecimerande inverkan studerades i kärlförsök. Sädesslagen visade sig ha sådan inverkan medan baljväxter som förfrukt höll rotbrandsnivån oförändrad eller höjde den, speciellt vid endast 1 växtperiods avbrytande odling. Förfrukternas inverkan varierade också betydligt enligt jordart. Flera växtperioders förfruktsodling skiljde sig från 1 văxtperiods odling av förfrukt sătillvida att ãven baljväxterna uppvisade positiv inverkan. Stora variationer i antalet förökningsenheter per gram jord för svampen Pythium kunde konstateras efter olika förfrukter. Korrelationen med rotbrand var dock för det mesta svag.

Betning av fröna med den systemiska fungiciden hymexazol och speciellt med hymexazol kombinerad med thiram gav tillräckligt skydd mot rotbrand under hjärtbladsstadiet, dvs. under sjukdomens dödande fas. Efter detta angreps plantorna, men angreppen var relativt lindriga. Betningen ökade beståndstätheten i olika försök med $7100-31200$ plantor per hektar och gav i medeltal ca $5-10 \%$ högre avkastning. Bandbesprutning av betorna strax efter uppkomst med hymexazol gav så gott som fullständigt skydd mot sjukdomen. Inverkan av en sâden behandling på avkastningens storlek i jämförelse med enbart fröbetning var dock obetydlig, med undantag av mycket kraftigt rotbrandsbesmittade lokaler. 